occasion may demand, containing information in regard to the work of the association and other matters of interest to old students. The association has accomplished some useful work during the first year of its existence. A register containing particulars of 729 old students has been published, steps are being taken with a view to secure academic costume for associates of the college, and inquiries are being made with the intention of offering evidence before the Royal Commission on University Education in London. We notice that Sir Thomas Holland, K.C.I.E., F.R.S., is the president of the association for the current year.

Mr. F. M. Denton, of the Carnegie Technical Schools, Pittsburgh, has been appointed to the post of associatehead of the electrical engineering and applied physics department of the Northampton Polytechnic Institute, Clerkenwell, London, E.C. rendered vacant by the resignation of Dr. C. V. Drysdale. Mr. Denton received his technical training at the Central 'Technical College of the City and Guilds of London Institute, and for a time he occupied a position on the staff of the electrical engineering department of the college. He left to join the staff of the General Electric Company in various departments at Pittsfleld, Mass., and at Schenectady. After occupying these positions for one year he was, two and a half years ago, appointed lecturer in electrical engineering at the new Carnegie Technical Schools at Pittsburgh, a position which he still occupies and is resigning to take up his London appointment.

THE Department of Agriculture and Technical Instruction in Ireland has distributed a circular (Form S 4I) giving full particulars of its summer courses of instruction for teachers, to be held, for the most part, in Dublin during July and August next. In July, courses will be conducted by the Department in, among other subjects, experimental science, laboratory arts, and drawing and modelling for teachers in day secondary schools, and in day and evening science and art classes; in domestic economy and woodwork for teachers in day secondary schools; and in hygiene and sick nursing and in housewifery for domestic economy instructresses. For August, four courses have been arranged, as follows:-in metalwork, practical mathematics and mechanics, and in handrailing, for teachers of wood-working; in industrial chemistry for teachers of chemistry in technical schools; in rural economy for teachers of experimental science in technical schools and teachers in national schools; and in school gardening for teachers in schools with gardens. The svllabuses of work contained in the circular show that great pains have been taken to provide practical courses dealing with subjects which will be directly useful to teachers in their work, and they should also serve the purpose of adding new life to their lessons when the teachers return to their schools.

ON Friday, March I , Sir William H. White, K.C.B., F.R.S., distributed the certificates and prizes at the Southwestern Polytechnic Institute, Chelsea. Mr. W. Hayes Fisher, M.P., occupied the chair. After the principal had read the report for he session 1908-9, and the certificates had been distributed, Sir William said that in education he has three articles of faith, namely :-(I) every child should have an opportunity for education; (2) all who give proof of capacity of profiting by higher training must be allowed to go on; (3) in getting the best educational results the natural process of gradual selection must be adopted and allowed to operate. This leads to apparent wastage; but there is no real wastage. It is necessary to have educated men of all grades in all works, and this has specially to be brought home to the English manufacturer, who does not yet realise the importance of higher education. Sir William said that in Chelsea he felt at home, for when he came from Devonshire, before he joined the Admiralty in 1867 , he studied at the School of Practical Shipbuilding at South Kensington, and lodged on King's Parade, Chelsea, almost within a stone's throw of the polytechnic. He was very pleased with his inspection of the polytechnic last week, and specially congratulated the governors on the large amount of their day work. From his experience of the technical colleges and institutes in London he had come to the conclusion that NO. $2 \mathrm{IO}_{7}$, VOL. 83] the polytechnics must be encouraged to carry on and extend day courses-their work in the evening was without parallel in the educational world. Various subjects must not be concentrated in special buildings, but each institute should make its courses as wide and as general as possible. London was so extensive, and its population was so large, that there was an ample field.

\section{SOCIETIES AND ACADEMIES. LONDON.}

Royal Society, March 10.-Sir Archiba'd Geikie, K.C.B., president, in the chair.-C. Gordon Douglas and Dr. J. S. Haldane: The causes of the absorption of oxygen by the lungs (preliminary). A short preliminary account is given of experiments affording clear evidence of a secretory activity of the lungs in the absorption of oxygen.- $\mathrm{V}$. $\mathrm{H}$. veley and A. D. Waller: The action of nicotine and other pyridine bases upon muscle, and on the antagonism of nicotine by curarine. Nicotine (mol. wt. $=162$ ) as such, or in the form of salt as nicotine tartrate, produces a very characteristic effect upon the contraction of isolated muscle. Its toxic power upon muscle, as compared with that of other substances that the authors have dealt with, is of the following order, i.e. approximately one-third that of quinine and considerably greater than that of curarine:-

$$
\begin{array}{lllllr}
\text { Aconitine } & \ldots & \ldots & \ldots & \ldots & \text { I0,000 } \\
\text { Quinine } & \ldots & \ldots & \ldots & \ldots & \text { 100 } \\
\text { Nicotine } & \ldots & \ldots & \ldots & \ldots & 33 \\
\text { Strychnine } & \ldots & \ldots & \ldots & \ldots & 12 \\
\text { Curarine } & \ldots & \ldots & \ldots & \ldots & 5
\end{array}
$$

The effect on muscle, characteristic of nicotine, is not produced by its parent base pyridine, nor by picoline, nor by piperidine. The order of toxicity upon muscle of these substances as compared with that of nicotine is as follows :-

$\begin{array}{lllllr}\text { Nicotine } & \ldots & \ldots & \ldots & \ldots & \text { 100 } \\ \text { Piperidine } & \ldots & \ldots & \ldots & \ldots & 50 \\ \text { Pyridine } & \ldots & \ldots & \ldots & \ldots & \text { 10 } \\ \text { Picoline } & \ldots & \ldots & \ldots & \ldots & \text { 10 }\end{array}$

As has been indicated by Langley, there is an antagonism between nicotine and curare. Using a solution of pure curarine iodide prepared by Prof. Boehm, we find that the characteristic effect of nicotine upon muscle is abolished when the proportion of curarine to nicotine, reckoned by molecules, is 2 to $I, 30$ to $r$, and 160 to 1 . With this last proportion a trace of nicotine effect can still be detected. In the case of other poisons, viz. strychnine, quinine, and aconitine, of which the effect per se upon muscle considerably exceeds that of curarine, there is, in a sense, an antagonism, as shown by abolition of the characteristic nicotine effect, but the abolition requires a greater mass of these more powerful poisons than is sufficient in the case of the less powerful poison-curarinc. Thus, approximately, whereas I mol. of curarine can overpower upwards of 100 mols. of nicotine, it requires $1 \mathrm{~mol}$. of strychnine or of quinine to overpower I mol. of nicotine, and $\mathrm{I} \mathrm{mol}$. of aconitine can overpower at most 10 mols. of nicotine. But in these cases the result appears to the authors to be intelligible as an effect of subdivision of muscle stuff between two poisons similar to the case of the subdivision of an acid between two bases; but this explanation is hardly applicable to the case of the antagonism of the strong poison nicotine by the rveak poison curarine.-Prof. $H$. E. Armstrong and E. H. Horton: Studies on enzyme action, xiii., enzymes of the emulsin type.-Miss M. P. FitzGerald: Preliminary note on the origin of the hydrochloric acid in the gastric tubules.-C. J. T. Sewell: The extinction of sound in a viscous atmosphere by small obstacles of cylindrical and spherical form. The results obtained in this paper are only valid when the dimensions of the obstacles are small compared with the wave-length of the incident sound. For cylinders and spheres the radius of which is not less than $10^{-3} \mathrm{~cm}$. it is found that the ratio of the lost energy to that incident upon the obstacle is at most of order $\mathrm{IO}^{-2}$; this is a very much larger proportion than is obtained in the case of a nonviscous air. The results obtained for a single obstacle are extended without difficulty to the case of a large number 
of obstacles. This extension is valid only when the space occupied by the obstacles is small compared with the total volume. It appears in the case of spherical obstacles that, if each small obstacle has radius $10^{-3} \mathrm{~cm}$., and there are $10^{6}$ of them per cubic centimetre, then sound of wavelength $50 \mathrm{~cm}$. will have its intensity diminished in the ratio of $\mathrm{I} / e$ after passing through a thickness of less than $12 \mathrm{~cm}$. of such a medium.-Dr. R. D. Kleeman: The ionisation of various gases by the $\beta$ rays of actinium. $A$ set of experiments carried out on the ionisation in various gases by the $\beta$ rays of actinium. The results are of interest in comparison with the ionisations produced by the $\beta$ rays of uranium, on account of the different penetrating powers of the rays. The results are exhibited in the subjoined tables. It will be seen that the relative ionisations by the $\beta$ rays of actinium are practically the same as those obtained with the $\beta$ rays of uranium.

Scattering of $\beta$ Rays.

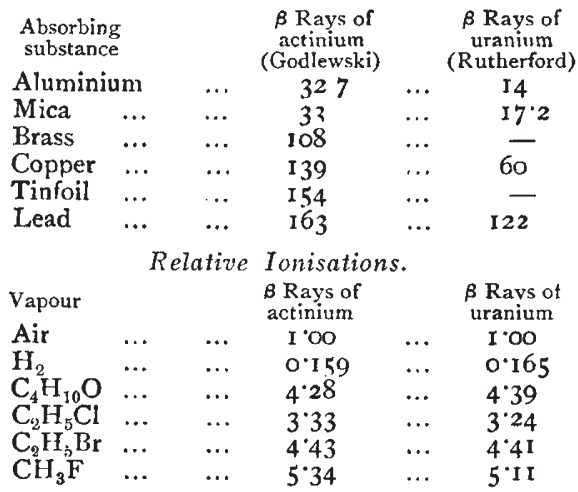

Geological Society, February 18.-Annual general meeting.-Prof. W. J. Sollas, F.R.S., president, in the chair. -Prof. W. J. Sollas : Anniversary address: the evolution of man in the light of recent investigations. Considering first the human remains of the Pleistocene epoch, the president pointed out that, so far as the evidence extends, it shows that the cranial capacity of the human skull increases rather than decreases as we pass backwards in time. The oldest known human skulls are later than the Chalky Boulder-clay. The cranial capacity is merely a morphological character of unknown significance. Observation shows that no discoverable connection exists between it and the intellectual power. The most recent researches in comparative anatomy emphasise the close connection between man and the anthropoid apes, especially the gorilla and the chimpanzee. A similar result is afforded by the investigations of Uhlenhuth and Nuttall into bloodrelationship. All recent researches converge to show that the genealogy of man is to be traced through the anthropoid apes and the catarrhine monkeys to the lemurs Cope's suggestion of a direct descent from extinct lemurs receives no confirmation. Primitive characters, when present in man, can be better explained by regression and adaptation. Man probably diverged from the phylum of the primates above the point of origin of the gibbon, and not far from that of the gorilla and the chimpanzee. $\mathrm{He}$ owed his prosess, in the first place, to emancipation from a forest life, and commenced his career as the ape of the plains. The erect attitude and the use of the hand as a universal instrument followed as a consequence. Ancestral man was probably a social animal at a very early period. and social life afforded a stimulus to the development of the powers of speech. He was probably distinguished by great bodily strength and by the possession of formidable natural weapors of defence and offence. With the invention of weapons made by art the necessity for natural weapons disappeared, and a regressive development of the teeth with adaptation to purely alimentary functions commenced. A purely human dentition characterises the Heidelberg jaw, which is the oldest known. This, however, still reveals in all other respects strong simian affinities. The growth of the brain in size and complexity might be correlated with the evolution and use of the hand, but to a far greater extent with the development of the powers of speech and the consequent exchange, multiplication, and coordination of ideas.

February 23.-Prof. W. W. Watts, F.R.S., president, in the chair.-T. O. Bosworth: Metamorphism around the Ross of Mull granite. The Ross of Mull granite is a coarsely crystalline plutonic mass, forming the western portion of the Ross of Mull, and extending over some twenty square miles. The intrusion is conspicuously later than the Moine rocks, and is regarded as one of the "newer granites." The rock shows very little evidence of faulting or movement of any kind, and is traversed by sheets of mica-trap. The eastern boundary of the granite is a very intricate line of junction with typical Moine schists and gneisses, into which it has been intruded. Injectionbreccias occur along the margin, where the granite is crowded with schist-inclusions. The changes in the pelitic schists are of two kinds, and are considered under the separate headings (a) impregnation, and $(b)$ thermal metamorphism.

Zoological Society, March 1.-Dr. A. Smith Woodward, F.R.S., vice-president, in the chair.--Sir G. F. Hampson : A list of the moths collected by Mr. Sheffield A. Neave in Rhodesia north of the Zambezi and the adjacent Katanga district of the Congo Free State. Nearly two hundred new species are described. The moth fauna of the district is mainly of a West African type, with a considerable admixture of East African and Mashonaland forms. As there are no high ranges of mountains or deep river valleys, the fauna presents a very uniform tropical African character, with no high mountain forms or forms peculiar to the faunas of the drier parts of southern or northern Africa.-T. H. Burlend: The urogenital organs of Chimaera monstrosa. This paper dealt with the urogenital organs of Chimæra, both immature and adult of each sex. Much of the early work of Leydig and Hyrtl which later writers had ignored or disputed, was now confirmed and supplemented.

Royal Anthropolngical Institute, March 8. - Sir Herbert Risley, president, in the chair.-Dr. A. Keith: The Gibraltar skull. This skull was presented to the Museum of the Royal College of Surgeons, England, some forty years ago by Mr. Edward Busk. Huxley had seen the cranium, but evidently did not recognise that it was of the same type as the Neanderthal skull. The merit of discovering that this skull was Neanderthaloid and belonged to that ancient Palæolithic race of men to which Schwalbe has given the specific name of Homo primigenius belongs to several anthropologists, but to Prof. Sollas must be ascribed the merit of having given quite recently in the Philosophical Transactions, the first detailet description. The skuil deserved further investigation, because it was the only specimen of Neanderthaloid man yet known that showed the face in a perfect condition. In the two recently discovered examples described by $\mathbf{M}$ Marcellin Boule and by Prof. Klaatsch, the facial arts were so mutilated that reconstruction was necessary to obtain an approximate conception of the original or natura form. Dr. Keith, with the aid of Mr. F. O. Barlow, had been able to obtain a cast of the interior of the skull, and was thus able to study certain surface markings of the brain. The brain-cast was remarkable for its width and for its flatness; the left occipital pole predominated over the right occipital pole, a character that has been associated with right-handedness. The fissure of Sylvius was wide and apparently open, but this character is due, as in native Australian brains, to the great size of the ridge of bone which occupies the fissure. It has been found possible to expose the sutures of the Gibraltar skull, and thus to localise definitely important points in its topography. The cerebral development of Palæolithic man has been very much underestimated. This is partly due to the fact that the height of the skull was measured from the inion to the glabella, two points which are fairly stationary in modern men, but which in Palæolithic men, as in anthropoids, grew upwards so as to occupy a relatively high position as regards the brain. These points are from 8 to to $\mathrm{mm}$. higher in Palæolithic men; hence the height of the skull, when measured from them, is comparatively low. M. Boule has found the capacity of the La Chapelle skull to be considerably above the average for modern Europeans, and such was undoubtedly the case as regards 
the Neanderthal and Spy crania. In the Gibraltar skull the capacity was low, below I Ioo c.c., a small amount, partly owing to the skull probably being that of a woman and also to the fact that it was pre-Neanderthaloid in type. Indeed, when rightly analysed, the Gibraltar individual, as regards the type of cranium and size of brain, is intermediate between Pithecanthropus and Palæolithic skulls, such as those of the La Chapelie man or the skull known as Spy ii. The mastoid of the Gibraltar skull is simian in type; the groove for the attachment of the digastric muscle is exposed laterally, as in the anthropoids, in place of being covered by the mastoid processes. Palæolithic men were distinguished by the width of the attachment of the skull to the neck, as well as by the simian supraorbital ridges. The nose of the Gibraltar individual is unlike anything yet seen in a human being. Although in certain features it shows approximation to the gorilla, it is best described as the precursor of the prominent European nose. The jaw is remarkable for its width; in length it does not much exceed that of a modern European. The third molar is larger than the second, at least one so infers from the parts that still remain. This shows a very robust dental development. It is evident that Palæolithic man had reached quite a modern degree of brain development. If the Gibraltar individual be assigned to a Palæolithic date, for we can assign its period only from its conformation, there being no accessory data then it must be assigned to a woman of a much lower brain development than the men now assigned to that period; but it is also possible that it belonged to a much earlier date than the Neanderthal-Spy men-to a race we know nothing of as yet. Dr. Keith also pointed out that in the pathological condition, known as acromegaly, the eyebrow ridges and attachment of the skull to the neck became enormously increased, thus reproducing a character which was normal in Palæolithic men. It seemed very probable that racia characters were determined by secretions of the mor obscure glandular organs of the body, especially the sexual slands.

Mathematical Society. March 10.-Sir W. D. Niven, president, in the chair.-J. W. Nicholson: The scattering of light by a large conducting sphere.-Miss H. P. Hudson: The 3-3 birational space transformation.W. F. sneppard: The expression of the sum of the $r$ th powers of the first $n$ natural numbers and other similar functions of $n$ in terms of $n+\frac{1}{2}$, and forms for the remainder in the Euler-Maclaurin sum-formula.

Linnean Society. March 3.-Mr. H. W. Monckton, treasurer and vice-president, in the chair.-W. Bickerton Our British nesting terns.

\section{PARIs.}

Academy of Sciences, Fehruary 28.-M. Émile Picard in the chair.-Emile Picard: A general theorem of certain integral equations of the third species.-J. Boussinesq The manner in which the potential of the velocities depends upon the initial state in the problem of waves by emersion.--A. Haller and A. Brochet: The oxidation of methyl ricinoleate by ozone. The ester fixes four atoms of oxygen on treatment with ozonised oxygen. The separation of the products formed by the interaction of this substance with sodium carbonate is described in detail; the position of the double linkage thus determined is in agreement with the constitution usually ascribed to this acid.-M. Lannelongue: A supplementary function of the foot in the yellow race. The foot in these races is not exclusively used for the support of the body. It is used for other functions, and becomes a prehensile organ, as in grasping an oar.-Emile Borel: A general condition of integrability.-Emile cotton: Astrmptotic solutions of differential equations.- Serse Bernstein: The conditions necessary and sufficient for the possibility of the problem of Dirichlet.-Joseph Marty: An integral equation.Léopold Fejér: A pair of conjugated Fourier's series.J. B. Fournier: A method of evaluating the temperature of superheated vapour. Superheated steam differs from saturated steam in that adjacent portions may have very different temperatures, and this fact has not been sufficiently appreciated in many instances when fixing the position of the thermometer designed to give the temperature of the superheated vapour. The error may amount to as much as $75^{\circ}$. The whole of the bulb, or corresponding portion of an electrical instrument, must be entirely immersed in the direct current of vapour, and contact with the walls of the pipe must be avoided.-Ch. Féry: A symmetrical coil for galvanometers with movable frame. G. Gabet: The results obtained in the radio-automatic torpedo by a new telecommutator. The principles upon which the apparatus is based were given in a previous communication. Practical tests in the Seine have been successfully carried out.-E. Louise: A new method of analysis by miscibility curves. Application to essence of turpentine. Aniline is a suitable solvent for this work, four curves obtained with this substance being illustrated. -E. Baud : Cryoscopy in concentrated solutions. The concentration is taken as the weight of the solute dissolved in a given volume (100 c.c.) of the solution, a nonpolymerised solvent being used. Results are given for ethylene bromide, benzene, and nitro-benzene as solvents. -G. Deniges : The detection of traces of formaldehyde in presence of acetaldehyde by fuchsine bisulphite. In liquids acid with sulphuric acid the red colour restored to the decolorised fuchsine solution by the acetaldehyde is much less stable than that produced by formaldehyde. The latter tends to increase on standing, the former to fade away.-F. Bodroux and F. Taboury: Syntheses effected with benzyl cyanide. Nitriles in ethereal solution react readily with sodium amide, giving sodium derivatives of the type R.CH.Na.CN. The latter can be converted into compounds R.CHR'.CN by alkyl halides. Several examples of the application of the reaction are given.-J. Bougoult: $\alpha$-Cyclogeranic acid. The acetate of trimethylcyclohexenol is obtained in good yield by heating $\alpha$-cyclogeranic acid with an acetic acid solution of mercuric acetate.-Marcel Delepine: The constitution of the dimeric aldehyde of crotonaldehyde.-A. Wahl and C silberzweig: The methyl methoxybenzoylacetates. The methyl esters, differing from the ethyl esters, can be distilled undecomposed in a vacuum. These compounds were prepared by Claisen's method. Details of the preparation and properties of these compounds are given.A. Backe: A new compound contained in food products. The reactions of this substance are sufficiently close to those of salicylic acid to give rise to the suspicion that the latter substance has been added. This body is formed by the action of heat on certain sugar and starches, and resembles the maltol of Kiliani and Barlen.-Louis Matruchot: A new group of pathogenic fungi causing sporotrichosis.-G. André : The development of a bulbous plant. Variations in the weight of the dry material.- Ed. Urbain, Cl. Scal, and A. Feige: The sterilisation of water by the uitra-violet rays. The source of light employed was an arc formed between carbons containing alumina. It is pointed out that it is useless to attempt to utilise wave-lengths below $1860 \AA$ ngström units, since a thin layer of quartz or water absorbs nearly all rays of lower wave-length.-Mlie. Cernovodeanu and Victor Menri: A comparison of the photochemical and abiotic action of the ultra-violet rays.-I. Chaine: The vertical position and the thigh muscles.-C. Vaney and A. Conte Researches on the development of the egg of the silkworm.-Paul Hallez: The summer and winter spawning of Prostoma lumbricoideum.-J. Nageotte: The microscopical study, during life, of the activity of the myeline in the course of the Wallerian degeneration of nerves. $\mathrm{M}$. Favre and $\mathrm{Cl}$. Regaud: Certain filaments having probably the signification of mitochondria in the generating layer of the epidermis.-F. Bordas: The medico-legal study of the benzidine reaction in the determination of blood spots. If the reaction is negative, blood is certainly absent; it is shown, however, that a positive reaction is given by substances other than blood.--E. Doumer and G. Lemoine: Obstinate neuralgic pains observed in patients suffering from excessive arterial tension.-Jean Brunhes: The predominance of erosion on the right bank of a river in times of flood.- Alfred Angot: The secular variation of the magnetic elements in the region of Paris.

March 7.-M. Émile Picard in the chair.-Maurice Hamy: The organisation of stellar spectroscopy at the Observatory of Paris. Details are given of the new

NO. 2107, VOL. 83] 
spectrograph, specially designed for the determination of radial velocities. Special attention has been given to securing constancy of temperature, with such success that the variations during several months have amounted to two- or three-hundredths of a degree.-J. Boussinesq : The integration of the equations of waves of emersion by Maclaurin's formula, in series always convergent, for a deep, endless canal and for an indefinite basin.-A. Haller and Ed. Bauer: The alkylation of fatty ketones by the use of sodium amide. By successive treatments with sodium amide and methyl iodide, pinacoline was converted into $\left(\mathrm{CH}_{3}\right)_{3} \cdot \mathrm{C} \cdot \mathrm{CO} \cdot \mathrm{CH}_{2} \cdot \mathrm{CH}_{3}$, and ultimately into

\section{$\left(\mathrm{CH}_{3}\right)_{3}$. C.CO.CH $\left(\mathrm{CH}_{3}\right)_{2}$.}

In benzene solution this was further acted upon by sodium amide and methyl iodide, the symmetrical hexamethylacetone $\left(\mathrm{CH}_{3}\right)_{3}$.C.CO.C $\left(\mathrm{CH}_{3}\right)_{3}$ being formed. Various derivatives of these ketones, together with the corresponding ethyl compounds, are described.-Richard Dedekind was elected a foreign associate.-H. Andoyer: New fundamental trigonometrical tables.-J. Guillaume: Observations of the sun made at the Observatory of Lyons during the third quarter of rgog. Observations were possible on sixty-seven days, the results being summarised in three tables, showing the number of spots, their distribution in latitude, and the distribution of the faculæ in latitude.Ch. Gallissot: The phenomenon of Purkinje. An experimental study of the luminosity of two points, red and blue. The brightness of these artificial stars could be altered by known amounts. It is concluded that Purkinje's phenomenon has no sensible influence from the sixth magnitude upwards.-Arnaud Denjoy: The measurement of ensembles.-M. de séguier: The symmetrical group and the alternating group.-W. Steklon: The development of an arbitrary function in series proceeding in accordance with certain fundamental functions.-Joseph Marty : Developments according to certain singular solutions.Sigismond Janiszewski : Contribution to the geometry of general plane curves.-M. Hadamard: Liquid waves. -Marcel Brillouin : Questions of mathematical physics. A. Dufour: Unsymmetrical triplets; an example of an asymmetry of position proportional to the square of the magnetic field. The chromium line 5247.56 forms a triplet in the magnetic field the axis of symmetry of which is displaced towards the violet. This asymmetry of position with respect to the initial line increases as the square of the field.-E. Caudrelier: The discharge of inductors: the capacity of the electrodes.-André Kling: A new method of estimating dextro-tartaric acid. The estimation is based on precipitation as calcium racemate--Léo Vignon: The diffusive power of certain artificial colouring matters. A study of diffusion shows that dye-stuffs considered as soluble in water fall into two clearly differentiated groups; those of the first group, of which picric acid is the type, form true solutions; those of the second group are only apparently soluble and are incapable of diffusion, such as Congo red.-Pierre Dupuis: The action of phosphorus trichloride upon guaiacol.-Aug. Chevalier: The forest resources of the Ivory Coast Results of the scientific expedition in western Africa. The products include kola and coffee, both in the wild state, a gum analogous to gum arabic, and several gumresins.-Auguste Joxe: The modes of opening of achenes and kernels at the time of germination.-Ed. Griffon: Variation in grafting and asexual hybridation.-Gabriel Vallet: The penetration and bactericidal action of the ultra-violet rays with respect to the chemical constitution of the media.- H. Bordier and R. Horand: The action of the ultra violet rays on trypanosomes. Trypanosoma lewisi in the blood of a rat was lilled by an exposure for fifteen seconds to the ultra-violet rays of a quartz mercury vapour lamp. These trypanosomes were absolutely un affected by a prolonged exposure to the X-rays.-Mme. Marie Phisalix : The natural immunity of batrachians and snakes against the poisonous mucus of the former: the mechanism of this immunity.-A. Briot: Properties of the serum of sero-anaphylactised rabbits. $-R$. Robinson: The dimensions of the cæcum and typhlectasis.-I. Thoulet: A lithological submarine map of the coast of Languedoc. -B. Calitzine : The determination of the epicentre of an earthquake from the data of a single seismic station.

\section{DIARY OF SOCIETIES.}

\author{
THURSDAY, MARCH 7
}

Royal Society, at 4.30.-Bakerian Lecture: The Pressure of Light 作 F.R.S., and Dr. Guy Barlow.

INSTITUTION OP EIECTRICAL ENGINEERS, at 8.-Further discussion (r) Short Circuiting of Large Electric Generators and the Resulting Forces on Armature Windings: (2) The Design of Turbo Field Magnets for A.C. Generators with Special Reference to Large Units at High Speeds: Miles Walker.

Institution of Mining and Metallurgy, at 8.-Annual Meeting.Followed by: The Surface Condenser in Mining Power Plant: W. A.

LINNEAN SOCIETY, at 8.-The Life-history of Chermes himalayensis, Steh. on the Spruce, Picea morinda, and Silver Fir, Abies Webbiana: E. P. Stebbing.-A Contribution toward a Knowledge of the Neotropical Thysanoptera: R. S. Bagnall.

Thysanoptera: R. S. Bagnall. Engineers, at 8.-Compounding and
Institution OF MEchanical EN STITUTION OF MECHANICAL ENGINEERS, at 8.

Superheating in Horwich Locomotives: G. Hughes. Optical Society, at 8. - Some Measurements of Stereoscopic Power D. P. Boatman and R. J. Lucking.-Optical Instruments for Nava Purposes: T. Y. Baker.

FRIDAY, MARCH 18

Royal Institution, at 9.-The Dynamics of a Golf Ball: Sir J. J. Thomson: F.R.S.

INTITUTION OF Civil ENGINEERS, at 8. - The Construction of Warships N. Maas.

Society OF Dyers and Colourists, at 8.-The Coal Tar Colour Industry of England; the Causes of its Progress and Retardation : Ignatius Singer.

\section{SATURDAY, MARCH IO.}

Royal InstiTution, at 3.- Electric Waves and the Electromagnetic Theory of Light: Sir J. J. Thomson, F.R.S.

\section{MONDAY, MARCH $2 \mathrm{I}$.}

Victoria Institute, at 4.30.-Light, Luminaries and Life: Rev. A Irving.

Institute of Actuaries, at 5.-(I) On the Valuation of the Payment on the Death of a Pensioner of the Excess of his Contributions, with or without Interest, over his Pension Payments; (2) On a Method of Scheduling Particulars for the Valuation, in certain cases, of Prospective Pensions based on Terminal Salaries: T. Tinner. TUESDAY, MARCH 22.

Institution of Civir. ENGINEers, at 8.-Further discussion: Birming ham Sewage-disposal Works: J. D. Watson.-Salisbury Drainage W. J. E. Binnie.

Geological Society, at 8 .

\section{WEDNESDAY, MARCH 23}

\section{CONTENTS.}

PAGE

The Life of Lord Kelvin. By Prof. A. Gray, F.R.S. $6 r$ Dynamic Electricity. By Prof. Gisbert Kapp . . . 65 An Artist-Ornithologist in Egypt . . . . . 66 The Evolution of Agriculture. By A. E. Crawley . 67 Our Book Shelf :-

Pettigrew : "A Manual of Locomotive Engineering" Redgrove: "Matter, Spirit, and the Cosmos"

Letters to the Editor:-

The Colour of Water.-Sir E. Ray Lankester, K.C.B., F.R.S.

The Stability of an Aëroplane.-W. H. Dines,

F.R.S. ; Prof. G. H. Bryan, F.R.S. . . . . Colour-Blindness. - Prof. Frank Allen

Practice and Knowledge. -Dr. John Aitken, F.R.

Accelerated Velocity of Jupiter's Red Spot Hollow. -

Scriven Bolton

A Radium Experiment, -F Harrison Glew '. Substitutes for Rubber. By C. Simmonds . . . . 7 Report of the Royal Commission on Canals . . . 72 Dr. E. Perceval Wright ........... 73

Notes ............. . . 74

Our Astronomical Column:-

Comet I9IOa.

Halley's Comet . . . . . . . . . . 79

Pidoux's Comet . . . . . . . . . . . . 79

The International Aëro and Motor Boat Exhibition

Explorations in the Glacier Tributaries of the Shayok River, Kashmir Territory. By Lieut. -

Colonel H. H. Godwin.Austen, F.R.S. . $\cdot$. Botanical Papers from Cambridge. By D. H. S.
The Production of Blackwater Fever. By Dr.

H. W. Armit Organisation of Technical Education. By

Dr. R. T. Glazebrook, F.R.S.

University and Educational Intelligence ..... 86

Societies and Academies . . . . . . . . . 87

Diary of Societies . . . . . . . . . . 90 